\title{
The Effect of Socioeconomy on Chronic Energy Deficiency among Pregnant Women in the Sudiang Raya Health Center, 2019
}

\author{
Nofita Setiorini Futri Purwanto ${ }^{1}$, Masni Masni ${ }^{2 \star}$, M. Nadjib Bustan ${ }^{3}$ \\ ${ }^{1}$ Department of Reproduction Health, Faculty of Public Health, Hasanuddin University, Makassar, Indonesia; ${ }^{2}$ Department \\ of Biostatistics, Faculty of Public Health, Hasanuddin University, Makassar, Indonesia; ${ }^{3}$ Department of Statistics, Faculty of \\ Mathematics and Natural Sciences, Makassar, Indonesia
}

Edited by: Mirko Spirosk Citation: Purwanto NSF, Masni, Bustan MN. The Effect of Socioeconomy on Chronic Energy Deficiency amon Pregnant Women in the Sudiang Raya Health Center, 2019 Open Access Maced J Med Sci. 2020 Sep 25; 8(T2):115-118. https://doi.org/10.3889/oamjms.2020.520
Keywords: Chronic energy less energy; Socioeconomic Keywords: Chronic energy less energy; Socioeconomic *Correspondence: Masni, Department of Reproduction Health, Faculty of Public Health, Hasanuddin University, Makassar, Indonesia. E-mail: masnimappajanci@rocketmail.com
Received: 09-Jul-2020
Revised: 11-Sep-2020
Accepted: 15-Sep-2020 E-mail: masnimappajanci@rocketmail.com
Received: 09-Jul-2020
Revised: 11-Sep-2020
Accepted: 15-Sep-2020 E-mail: masnimappajanci@rocketmail.com
Received: 09-Jul-2020
Revised: 11-Sep-2020
Accepted: 15-Sep-2020 Copyright: ๑ 2020 Nofita Setiorini Futri Purwanto

Funding: This research did not receive any financia Competing Interests: The authors have declared that no competing interests exis

Open Access: This is an open-access article distributed under the terms of the Creative Commons AttributionNonCommercial 4.0 International License (CC BY-NC 4.0)

\section{Abstract}

BACKGROUND: Chronic energy deficiency (CED) is a condition of malnutrition of pregnant women which have an advanced impact in the form of health problems and complications in the mother and baby. For this reason, it is necessary to work toward prevention by knowing the socioeconomic influence on CED.

AIM: The aim of the study was to determine the effect of socioeconomics on the incidence of CED in pregnant women.

METHODS: This research is observational analytic with case-control research design. A sample of 99 pregnant women was taken from the working area of the Sudiang Raya Health Center. This sample consisted of 33 case groups of mothers with CED and 66 control groups of pregnant women who did not suffer from CED who had met the inclusion and exclusion criteria of the study. Data were analyzed using analysis Chi-square and multiple logistic regression.

RESULTS: The results showed that maternal occupation $(p=0.018$; odds ratio $[\mathrm{OR}]=6.091$; confidence interval [CI] $95 \%$ 1.367-27.133) was significant for CED, whereas that education $(p=0.213$; OR $=0.593 ; \mathrm{Cl} 95 \% 0.260-1.351)$ and income $(\mathrm{p}=0.576 ; \mathrm{OR}=0.733 ; 95 \% \mathrm{Cl} 0.247-2.179)$ are not significant to CED. Based on multivariate analysis we found that the most influential factor was occupation (adjusted $\mathrm{OR}=11.734, \mathrm{Cl} 95 \% 1.253-109.91$ ).

CONCLUSION: Based on the results of research and discussion, it can be concluded that work affects the CED in pregnant women, while maternal education and income have no effect on CED in pregnant women. Occupation is the most influential factor on the CED, women who do not work have a risk of 11.734 times experiencing CED compared to women who work.

\section{Introduction}

Globally, malnutrition is an important health problem, especially in children under five and pregnant women. The World Health Organization (WHO) classifies malnutrition as the biggest threat to public health. Chronic energy deficiency (CED) is one of the conditions of malnutrition, a state of fertile age women (WUS) suffering from chronic food shortages (chronic), which results in relative or absolute health problems arising from one or more nutrients [1].

The proportion of pregnant women with chronic energy deficiency based on Basic Health Research in 2013 was $38.5 \%$ and experienced a significant decrease in 2018 to $17.3 \%$. In South Sulawesi Province, chronic energy deficiency cases experienced an upward trend in 2017, reported $15.9 \%$ of cases, and increased in 2018 to $16.9 \%$ [2]. While in Makassar City in 2017 , there were $8.43 \%$ of pregnant women chronic energy deficiency and experiencing a significant increase in 2018 , the proportion of pregnant women chronic energy deficiency is $11.44 \%$. Of the 47 health center in Makassar City, the highest health center in the proportion of chronic energy deficiency, namely,
Sudiang Raya in 2017 , there were $7.52 \%$ cases, and in 2018 , there were $16.12 \%$ [2].

The main determinants of nutritional status are economic status as indicators of access to adequate family food, use of health services, availability of water sources, and sanitation facilities [3]. Several studies have shown that chronic energy deficiency is influenced by factors, including age, knowledge, genetics, obstetrics, diet, food intake, illness, physical and socio-economic activities, including education, employment, and income. Based on the description, that the cause of chronic energy deficiency in pregnant women is not just a single factor, but there are several influences; therefore, this study aims to find out more about the socio-economic effect on chronic energy deficiency in pregnant women at the Sudiang Raya Public Health Center.

\section{Materials and Methods}

The research was performed using quantitative methods, design analytic observational with a approach 
case-control with matching the distance of pregnancy in the control group and a distance of $<2$ years and $>2$ years. The factors, in this study (education, employment, and income), are independent variables, while the CED events are the dependent variable. The study was conducted from September to October 2019 in the working area of the Sudiang Raya Health Center in Makassar City.

The population in this study were all pregnant women giving birth in the working area of Sudiang Raya Health Center, Makassar City, in 2018. The sample in this study consisted of 99 respondents in the case group is pregnant women who experienced chronic energy deficiency and the control group is pregnant women who did not experience chronic energy deficiency, with a case: control sample ratio of $1: 2$, so the minimum sample size was 33: 66 .

This study uses primary data that are directly taken or obtained by researchers from respondents using a questionnaire (list of questions). The data contain the respondent's identity, age, pregnancy distance, education, employment, and income.

The data analysis technique of this study used univariate, bivariate analysis with test Chi-square, and multivariate analysis with multiple logistic regression with SPSS 21.0 for windows program.

\section{Results}

Table 1 shows the characteristics of respondents. The majority of reproductive age (20-35 years) are $90.9 \%$ and are the age range recommended by the WHO for safe and good age for pregnant women, while in risk groups ( $<20$ years and $>35$ years), that is, $9.1 \%$. Pregnancy distance, pregnant women with a risk pregnancy distance of $<2$ years ( $<2$ years) is $24.2 \%$, and the pregnancy interval are more than 2 years ( $\geq 2$ years) of $75.8 \%$. Education, mothers with low education (elementary and junior high) in the case and control, had the same proportion, amounting to $33.3 \%$. Likewise, mothers with higher education (high school and university) in cases and controls had the same proportion of $66.7 \%$. Occupation, the average pregnant woman, does not work in cases of $97.0 \%$ greater than the control (78.8\%). Revenue $<2,860,382$ (UMK Makassar city) in the case amounted to $72.7 \%$ greater than the control $(63.6 \%)$.

Table 2 shows that the results of an analysis of the effect of education on chronic energy deficiency show a $p=1.000$ with an odds ratio $(O R)=1.000 ; 95 \%$ confidence interval $(\mathrm{Cl}) 0.412-2.426$ that education is not significant which means that there is no influence of education on chronic energy deficiency. Analysis of the effect of work on chronic energy deficiency shows the $p=0.017$ with OR $=8.615 ; 95 \%$ Cl 1.081-68.686 that work is significant which means that there is an effect of work on chronic energy deficiency. Pregnant women who do not work at risk 8.615 times experience chronic energy deficiency compared to pregnant women who work.

Table 1: Distribution of respondent characteristics based on pregnancy in the work area of Sudiang Raya Health Center in 2019

\begin{tabular}{|c|c|c|c|c|c|c|}
\hline \multirow[t]{2}{*}{ Variable } & \multicolumn{2}{|c|}{ Case } & \multicolumn{2}{|c|}{ Control } & \multicolumn{2}{|c|}{ Total } \\
\hline & $n$ & $\%$ & $n$ & $\%$ & $n$ & $\%$ \\
\hline \multicolumn{7}{|l|}{ Age during pregnancy } \\
\hline Age $<20^{\text {th }}$ and $>35^{\text {th }}$ & 3 & 9.1 & 12 & 18.2 & 15 & 15.2 \\
\hline Age $20-35 \mathrm{Th}$ & 30 & 90.9 & 54 & 81.8 & 84 & 84.8 \\
\hline \multicolumn{7}{|l|}{ Distance of pregnancy } \\
\hline$<2$ Years & 8 & 24.2 & 16 & 24.2 & 24 & 24.2 \\
\hline$\geq 2$ Years & 25 & 75.8 & 50 & 75.8 & 75 & 75.8 \\
\hline \multicolumn{7}{|l|}{ Education } \\
\hline Low & 11 & 33.3 & 22 & 33.3 & 33 & 33.3 \\
\hline High & 22 & 66.7 & 44 & 66.7 & 66 & 66.7 \\
\hline \multicolumn{7}{|l|}{ Work } \\
\hline Not working & 32 & 97.0 & 52 & 78.8 & 84 & 84.8 \\
\hline Working & 1 & 3.0 & 14 & 21.2 & 15 & 15.2 \\
\hline \multicolumn{7}{|l|}{ Income } \\
\hline$<$ UMK & 24 & 72.7 & 42 & 63.6 & 66 & 66.7 \\
\hline$\geq U M K$ & 9 & 27.3 & 24 & 36.4 & 33 & 33.3 \\
\hline
\end{tabular}

Table 2 shows that the results of the analysis of the effect of income on chronic energy deficiency show the $p=0.366$ with $\mathrm{OR}=1.524 ; 95 \% \mathrm{Cl} 0.610-3.807$, that income is not significant which means that there is no influence of income on chronic energy deficiency.

Table 2: Bivariate analysis of socio-economic effects on chronic energy deficiency in the work area of Sudiang Raya Health Center in 2019

\begin{tabular}{|c|c|c|c|c|c|c|c|c|c|c|}
\hline \multirow[t]{2}{*}{ Variable } & \multicolumn{2}{|c|}{ Case } & \multicolumn{2}{|c|}{ Control } & \multicolumn{2}{|c|}{ Total } & \multirow[t]{2}{*}{$\mathrm{p}$-value } & \multirow[t]{2}{*}{ OR } & \multicolumn{2}{|c|}{$95 \% \mathrm{Cl}$} \\
\hline & $\mathrm{n}$ & $\%$ & $\mathrm{n}$ & $\%$ & $\mathrm{n}$ & $\%$ & & & Lower & Upper \\
\hline \multicolumn{11}{|l|}{ Education } \\
\hline Low & 11 & 33.3 & 22 & 33.3 & 33 & 33,3 & 1.000 & 1.000 & 0.412 & 2.426 \\
\hline High & 22 & 66.7 & 44 & 66.7 & 66 & 66.7 & & & & \\
\hline \multicolumn{11}{|l|}{ Jobs } \\
\hline Not working & 32 & 97.0 & 52 & 78.8 & 84 & 84.8 & 0.017 & 8.615 & 1.081 & 68.686 \\
\hline Working & 1 & 3.0 & 14 & 21.2 & 15 & 15.2 & & & & \\
\hline \multicolumn{11}{|l|}{ Income } \\
\hline$<$ UMK & 24 & 72.7 & 42 & 63.6 & 66 & 66,7 & 0.366 & 1.524 & 0.610 & 3.807 \\
\hline$\geq$ UMK & 9 & 27.3 & 24 & 36.4 & 33 & 33.3 & & & & \\
\hline
\end{tabular}

Table 3 shows the results of the multiple logistic regression analysis by looking at the higher influence values which are looking at the value Wald and the $\mathrm{p}$-value so that the most influential is work after being controlled with education and income variables with a value Wald of 4.654 and a $p=0.031$ OR (adjusted $\mathrm{OR})=11.734, \mathrm{Cl} 95 \% 1.253-109.918$ that pregnant women who do not work are 11.734 times more likely to experience CED compared to working mothers.

Table 3: Logistic regression test results of socio-economic impacts on CED in pregnant women in the work area of Sudiang Raya Health Center in 2019

\begin{tabular}{lllllllll}
\hline Variable & $\mathrm{B}$ & $\mathrm{SE}$ & Wald & Df & $\mathrm{p}$-value & $\mathrm{OR}$ & \multicolumn{2}{c}{ 95\% Cl for Exp.(B) } \\
\cline { 7 - 9 } & & & & & & & Lower & Upper \\
\hline Education & -0.284 & 0.480 & 0.350 & 1 & 0.554 & 0.753 & 0.294 & 1.930 \\
Occupations & 2.462 & 1.14 & 4.654 & 1 & 0.031 & 11.73 & 1.253 & 109.91 \\
Income & -0.257 & 0.556 & 0.213 & 1 & 0.644 & 0.774 & 0.260 & 2.299 \\
Constant & -204 & 1.276 & 0.890 & 1 & 0.345 & 0.300 & & \\
\hline
\end{tabular}

\section{Discussion}

In this study, there are three variables studied, namely, education, occupation, and income. It can be 
seen that from the three variables studied, there is one variable that significantly influences the CED, namely, occupation.

The results of this study indicate that employment is a significant influence factor on CED. This study is in line with research in Metro City, Lampung Province using a design case-control by looking at the effects of demographics and socioeconomics on the incidence of CED with $(O R=17.50)$, so mothers who do not work 17.50 times have more CED compared to mothers who work [4]. Ernawati [5] regarding the relationship of age and occupational status with the incidence of CED in pregnant women show that there is a relationship between maternal employment status and CED in pregnant women, pregnant women who do not work at risk of experiencing CED by 9.286 times compared to pregnant women who work. The results are similar to Kotut [6] in Kenya that the proportion of unemployed mothers is more likely to experience CED $(68 \%)$ than working mothers $(2 \%)$.

Mahirawati research [7] shows that there is a significant relationship between maternal work and the incidence of CED in pregnant women. Someone who works will be more socially interacting in the association so that it can increase knowledge and easily obtain information about health so that it is more selective to meet nutritional needs and choose food to consume.

Work is closely related to economic status, economic status affects the choice of food consumed daily, and working mothers have their own income more easily meet their nutritional needs [1]. Someone with a higher education level tends to choose better food compared to a lower education level. This study shows that maternal education has no effect on the incidence of chronic energy deficiency (CED). The results of the research show that the average respondent has a history of senior secondary education (SMA).

The results of this study are in line with the research of Teguh [8] stating that there is no significant relationship between the level of education and the incidence of CED in pregnant women. Opportunities for CED events in low education are 2.3 times higher than pregnant women with higher education levels in line with the Kotut [6] study conducted in 2014, in which the proportion of mothers with higher education had less CED than mothers with low education. The same results as the research of Ahmad [9] showed that education was not related to the CED occurrence in pregnant women but, in proportion to primary education, more experienced CED than secondary education.

The ability of families to buy food depends on the size of the family income. Families with limited income will most likely not meet the nutritional needs of their bodies. This study shows that income is insignificant with the incidence of chronic energy deficiency, the results of the study indicate that the proportion of mothers with family income above UMK is less likely to experience CED than mothers who have income below UMK.

Marsedi et al. [10], in the Sei Jang Health Center in Bukit Bestari District, stated that there is no relationship between family income and the incidence of chronic energy deficiency in pregnant women. In theory, income is a factor that affects the lack of chronic energy, family income determines the quality and quantity of dishes in the family [11], [12]. However, in this study, income is not at risk for CED because in both cases and controls the average monthly income of families < UMK Makassar city.

This study is in line with the study of Wati et al. [13] about the relationship of knowledge about nutrition, family income, and soil-transmitted helminths infestation with CED in the Sungai Siak Pekanbaru coastal area that there is no meaningful relationship between income and chronic energy deficiency. Similar to the research by Petrika et al. [14] in Sedayu District, Bantul show that there is no significant relationship between the level of income and the risk of chronic energy deficiency in pregnant women. The results of this study are not in line with the study of Daba et al. [15] in the East Wollega Zone of Ethiopia showing that income is significant to the nutritional status of mothers $(\mathrm{AOR}=5.670$ (2.082-15.439). Mothers with low incomes are 5.670 times more at risk of developing CED events compared to mothers with high income.

\section{Recommendation}

It is recommended to use lemongrass in preventing elevated blood uric acid levels.

\section{Conclusion}

Based on the results of research and discussion, it can be concluded that work affects the CED in pregnant women, while maternal education and income have no effect on CED in pregnant women. Occupation is the most influential factor on the CED, women who do not work have a risk of 11.734 times experiencing CED compared to women who work.

\section{References}

1. Arisman MB. Gizi Dalam Daur Kehidupan. Jakarta: Penerbit Buku Kedokteran EGC; 2010.

2. Kemenkes RI. Penelitian badan laporan nasional rise kesehatan dasar. Badan Litbangkes Jakarta: Kementerian Kesehatan Republik Indonesia; 2018.

3. Devgun P, Mahajan SL, Gill KP. Prevalence of chronic energy 
deficiency and socio demographic profile of women in slums of Amritsar city, Punjab, India. J Res Health Sci Int. 2014;2(2):52732. https://doi.org/10.33545/comed.2019.v2.i1a.12

4. Anggraini Y. Pengaruh demografi dan sosioekonomi pada kejadian kekurangan energi kronik ibu hamil di kota metro provinsi lampung. J Kesehatan. 2013;4(2):401-8. https://doi. org/10.37413/jmakia.v4i1.28

5. Ernawati A. Hubungan usia dan status pekerjaan ibu dengan kejadian kurang energi kronis pada ibu hamil relationship age and occupational status with chronic energy deficiency in pregnant woman. J Litbang. 2018;14(1):27-37. https://doi. org/10.33658/jl.v14i1.106

6. Kotut J, Wafula S, Ettyang G, Mbagaya G. Protein-energy malnutrition among women of child bearing age in semiarid areas of Keiyo district, Kenya. Adv Life Sci Technol. 2014;24:80-92

7. Mahirawati VK. Faktor-faktor yang berhubungan dengan kekurangan energi kronis (KEK) pada ibu hamil di kecamatan kamoning dan tambelangan, kabupaten sampang, Jawa Timur. Bul Penelitian Sist Kesehatan. 2014;17(2):193-202. https://doi. org/10.32883/hcj.v2i3.78

8. Teguh NA, Hapsari A, Dewi PR, Aryani P. Faktor-faktor yang mempengaruhi kejadian kurang energi kronis (KEK) Pada ibu hamil di wilayah kerja UPT puskesmas I pekutatan, Jembrana, Bali. Intisari Sains Med. 2019;10(3):506-10. https://doi. org/10.15562/ism.v10i3.432

9. Ahmad R, Djami ME, Agustina SD. Related of knowledge and characteristics of pregnant women with chronic energy deficiency in health public center at mauk tangerang. J Bina Cendekia Kebidanan. 2016;2(1):198-204.
10. Marsedi GS, Widajanti L, Aruben R. Hubungan sosial ekonomi dan asupan zat gizi dengan kejadian kurang energi kronik (kek) pada ibu hamil di wilayah puskesmas sei jang kecamatan bukit bestari kota tanjung pinang tahun 2016. J Kesehatan Masyarakat. 2017;5(3):138-47. https://doi.org/10.33221/jikes. v18i1.189

11. Mallongi A, Stang, Syamsuar, Natsir MF, Astuti RD, Rauf AU, et al. Potential ecological risks of mercury contamination along communities area in tonasa cement industry Pangkep, Indonesia. Enferm Clín. 2020;30(4):119-22. https://doi. org/10.1016/j.enfcli.2019.10.054

12. Mallongi A, Limbong $E$, Naiem $F$, Ishak $H$, Basri $S$, Saleh $M$, et al. Health risk analysis of exposure to mercury $(\mathrm{Hg})$ and cyanide (CN) in Kayeli village communities Teluk Kayeli district Buru regency. Enferm Clín. 2020;30(4):427-30. https://doi. org/10.1016/j.enfcli.2020.03.007

13. Wati L, Ernalia $Y$, Haslinda L. Hubungan pengetahuan mengena gizi, pendapatan keluarga dan infestasi soil transmitted helminths dengan kurang energi kronik (kek) pada ibu hamil di daerah pesisir sungai siak pekanbaru. JOM. 2012;1(2):1-10. https://doi.org/10.26891/jik.v4i1.2010.14-19

14. Petrika $\mathrm{Y}$, Hadi H, Nurdiati DS. Tingkat asupan energi dan ketersediaan pangan berhubungan dengan risiko kekurangan energi kronik (KEK) pada ibu hamil. J Gizi Diet Indones. 2014;2(3):140-9. https://doi.org/10.21927/ ijnd.2014.2(3).140-149

15. Daba G, Beyene F, Fekadu H, Garoma W. Assessment of knowledge of pregnant mothers on maternal nutrition and associated factors in Guto Gida Woreda, East Wollega Zone, Ethiopia. J Nutr Food Sci. 2013;3(6):1-7. https://doi. org/10.4172/2155-9600.1000235 